\title{
TIRE CASINGS AND THEIR MATERIAL CHARACTERISTICS FOR COMPUTATIONAL MODELING OF TIRES
}

\author{
Jan Krmela, Vladimira Krmelova \\ Alexander Dubček University of Trenčín, Slovakia \\ jan2.krmela@post.cz,jan.krmela@fpt.tnuni.sk
}

\begin{abstract}
The report is focused on determination of the material parameters from experimental data, which will be used as input data to computational modeling of radial tires for passenger vehicles. It is necessary to have knowledge about the geometry, material parameters, cross-section and structure of tire casing (number of layers of the belt and carcass, information about the bead and cap ply) for creation of computational models of tire casing for stress-strain analysis of a tire under vertical load, modal analysis etc. The tire casing parts in computational models are partially replaced with material and geometrical parameters with specified stiffness. The Finite Element Method using the program system ANSYS is applied to the computational modeling. The experiments of total tires are needed for verification analyses between computational results and experimental data. The experiments of parts of the tire casing such as parts of tread and next rubber parts of tire are needed for determination of the parameters of constitutive models of rubber elasticity such as the parameters of hyperelastic Mooney-Rivlin model. The report describes the result for two tires 165/65 R13 and 215/40 R17 as samples. The structures of the tire-crown with geometrical and material parameters are presented. The authors used orthotropic material parameters for determination of the structure parts of tire as the steel-cord belt. The values of modules of elasticity and Poisson ratios are presented for 165/65 R13. The orthotropic material parameters for definition of the tire-crown of 215/40 R17 are determined as input data to the computational model of tire.
\end{abstract}

Keywords: tire, composite, rubber, FEM, ANSYS, Mooney-Rivlin.

\section{Introduction}

The report is closely related to the contribution Composites with Nonlinear Matrix for Transport Means - Experimental and Computational Modeling presented at the conference Engineering for Rural Development in 2011 [1]. Radial tire for passenger vehicles can be classified as polycomponent composite with a rubber matrix reinforced with textile and steel cords [2]. The structure parts applied into these tires are the textile carcass, textile overlap belt and steel-cord belt. These structures of tire have got a different cord-angle and numbers of layers, e.g. Figure 1a for tire 165/65 R13 for standard cars and Figure 1b for tire 215/40 R17 (low profile, extra load) for sport cars as samples of crosssections. The maximal inflation pressure of tire $215 / 40 \mathrm{R} 17$ is 3.4 bars and maximal load is $545 \mathrm{~kg}$ (load index is 87), the tire 165/65 R13 has 3.0 bars as the maximum inflation pressure and $412 \mathrm{~kg}$ as maximum load (load index is 77). The truck tires or agriculture tires have different structures [3; 4].

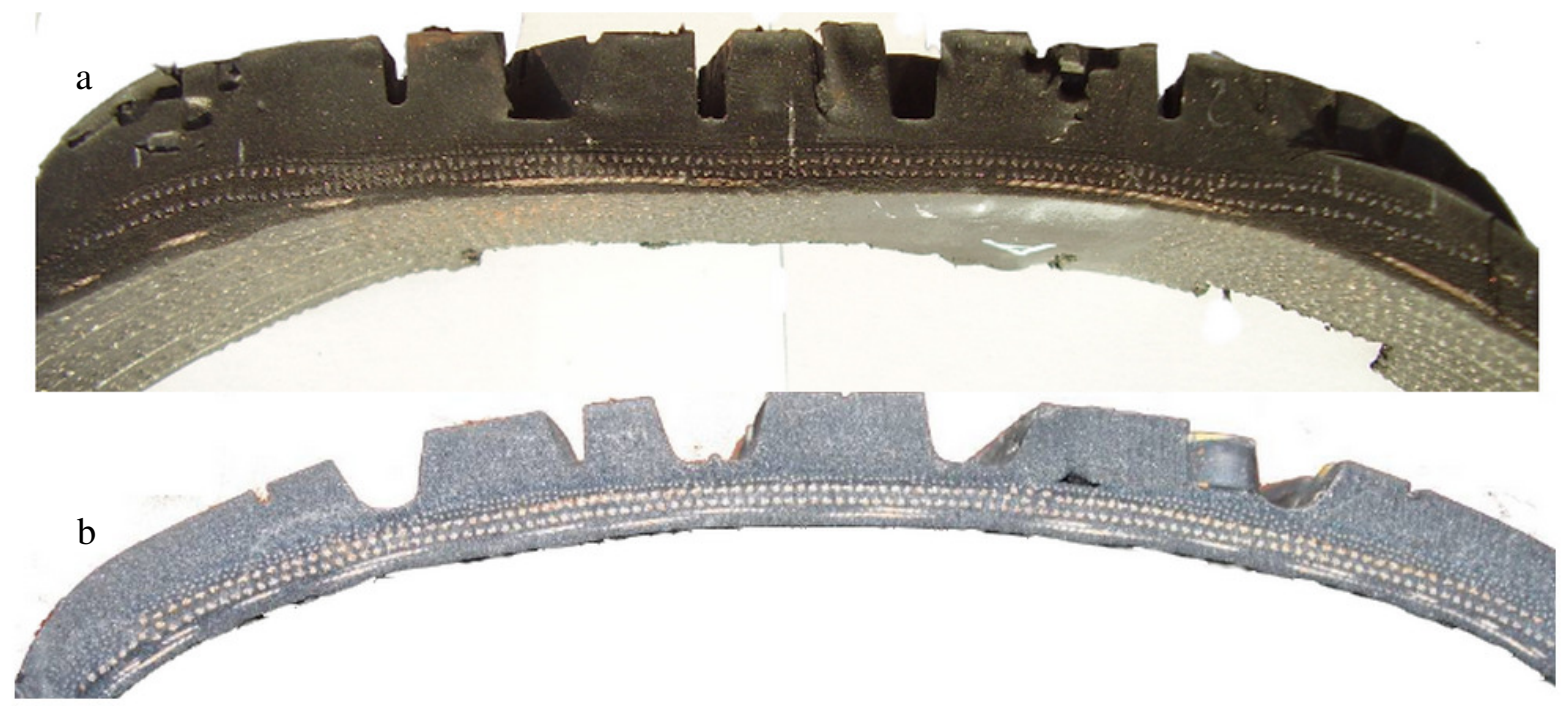

Fig. 1. Tire-crown area: a - tire 165/65 R13; b - tire 215/40 R17 
Fig. 2 presents details of the structure in the tire-crown of tires. The tire 165/65 R13 has a tire carcass which consists of one layer of polyester and the tread consists of two layers of the steel-cord belt and two layers of the polyamide belt. The steel-cord belt density is 96.1 ends per decimeter.

The aim of the study is to create a computational model, which describes the static and dynamic loading of tire for given inflation pressure. For creation of computational models strain-stress analyses of the tire are necessary to have a good knowledge about the geometrical parameters of the structure of tire-casing and material parameters of cords and rubbers into tire.

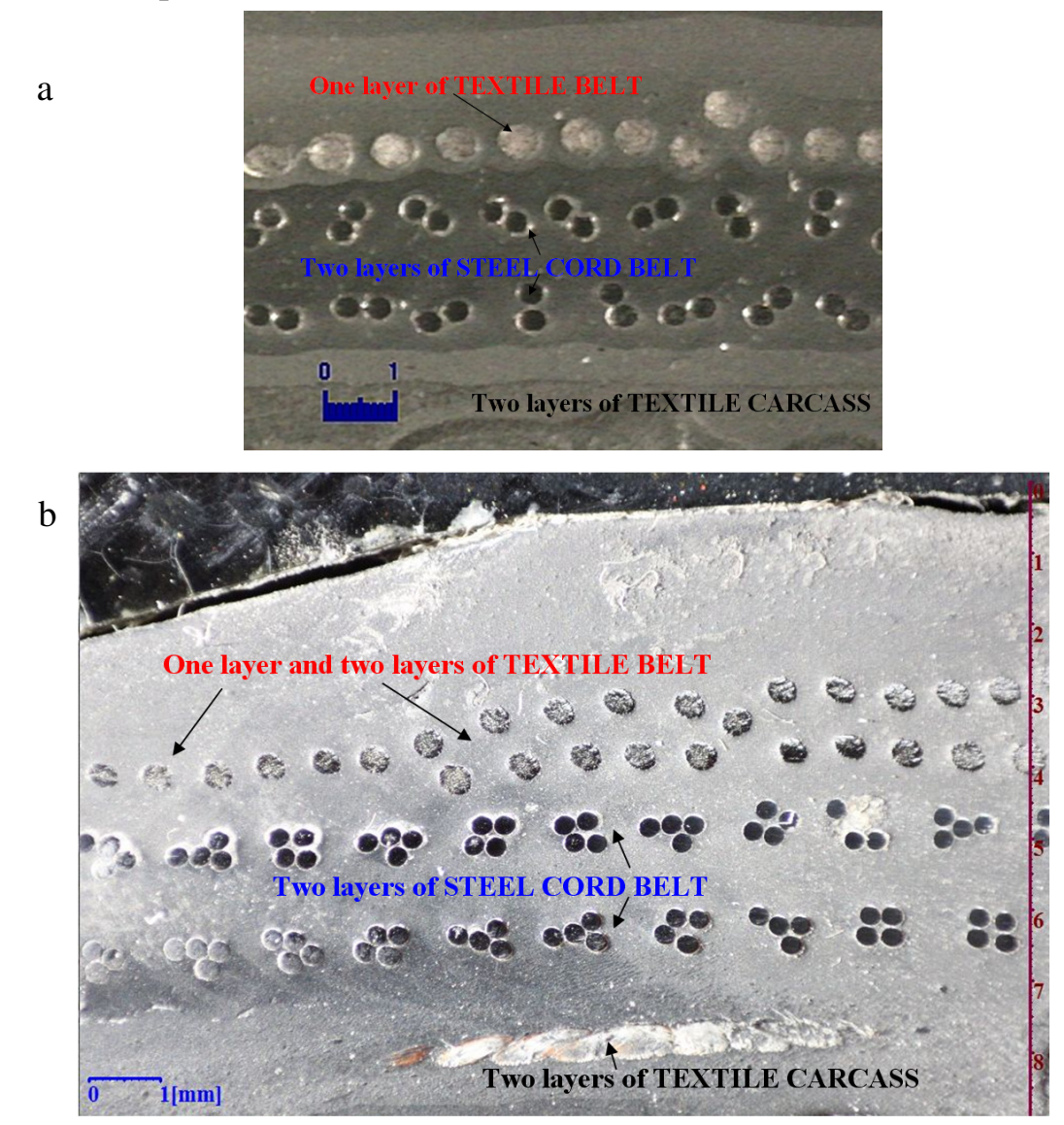

Fig. 2. Detail of structure tire-crown: a - tire 165/65 R13; b - tire 215/40 R17

\section{Materials and methods}

Geometrical parameters of the structure parts of tire 215/40 R17 as the diameters of cords are given in Figure 3 and Table 1. The cord angle us not measured. For the description of elastomer parts of tires the hyperelastic Mooney-Rivlin model is used, which is described by the two Mooney-Rivlin parameters. The Mooney-Rivlin model can be well applied for the range of elongation up to $150 \%$. To determine the basic Mooney-Rivlin parameters $\mathrm{C}_{10}$ and $\mathrm{C}_{01}$ it is necessary to carry out the mechanical tensile test for a sample from the given elastomer [5]. The authors used the FEM program ANSYS for determination of the Mooney-Rivlin parameters from tensile tests of elastomers. The values of the Mooney-Rivlin parameters are given in Table 2 for the tire 165/65 R13 as a sample of the results.

Parameter $d$ is incompressibility parameter and this parameter is calculated by formula (1).

$$
d=\frac{2(1-2 P R)}{C_{10}(5 P R-2)+C_{01}(11 P R-5)},
$$

where $C_{10}, C_{01}$ - material parameters of Mooney-Rivlin model, MPa;

$P R$ - Poisson ration (for rubber it is 0.5 ). 


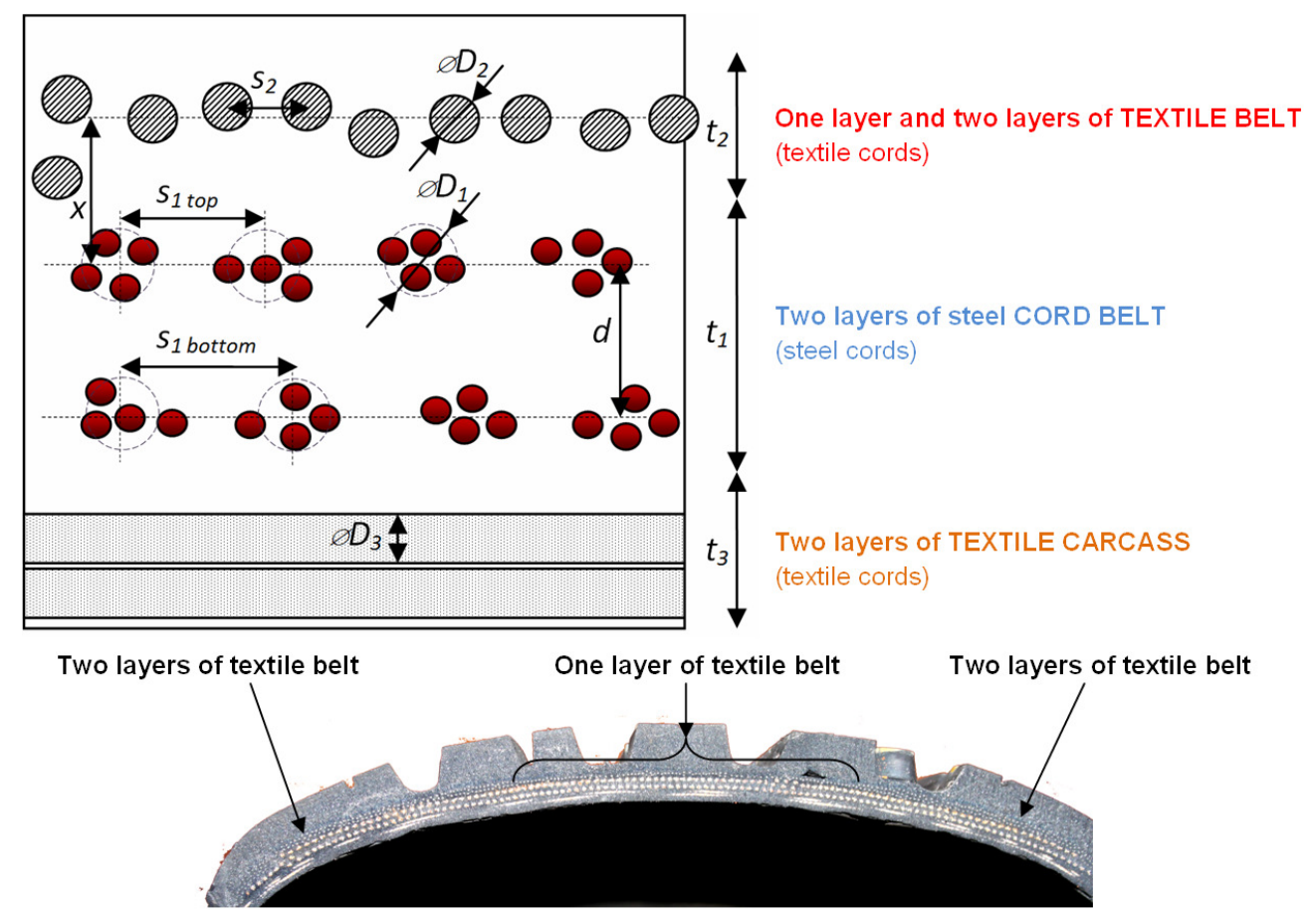

Fig. 3. Legend of geometrical parameters of structure parts of tire 215/40 R17

Values of geometrical parameters of structure parts of tire 215/40 R17

\begin{tabular}{|c|c|c|c|}
\hline Structure parts of tire & Steel-cord belt & $\begin{array}{c}\text { Textile } \\
\text { overlap belt }\end{array}$ & $\begin{array}{l}\text { Textile } \\
\text { carcass }\end{array}$ \\
\hline Number of layers & 2 & 1 and 2 & 2 \\
\hline Thickness of layers $t, \mathrm{~mm}$ & $\begin{array}{c}t_{1} \\
2 \times(1.38 \div 1.44)\end{array}$ & $\begin{array}{c}t_{2} \\
1.10 \text { and } 1.75\end{array}$ & $\begin{array}{c}t_{3} \\
1.40 \div 1.50\end{array}$ \\
\hline Diameter of cords $D, \mathrm{~mm}$ & $\begin{array}{c}D_{1} \\
0.80\end{array}$ & $\begin{array}{c}D_{2} \\
0.44\end{array}$ & $\begin{array}{c}D_{3} \\
0.50\end{array}$ \\
\hline Construction of steel-cords & $2+2 \times 0.30(4 \times 0.30)$ & - & - \\
\hline $\begin{array}{l}\text { Distance between middles of steel-cords } \\
\text { in top and bottom layers } d, \mathrm{~mm}\end{array}$ & $\begin{array}{c}d \\
1.45 \div 1.55\end{array}$ & - & - \\
\hline $\begin{array}{l}\text { Spacing between middles of cords } \\
\text { in layer } s, \mathrm{~mm}\end{array}$ & $\begin{array}{c}s_{1 \text { top }} 1.35 \text { for top layer } \\
s_{1 \text { bottom }} 1.40 \div 1.55 \text { for } \\
\text { bottom layer }\end{array}$ & $\begin{array}{c}s_{2} \\
0.70 \div 0.75\end{array}$ & - \\
\hline $\begin{array}{l}\text { Number of steel-cords per decimeter width } \\
\text { of one steel-cord belt layer, } 10 \mathrm{~cm}^{-1}\end{array}$ & $\begin{array}{c}68 \text { for top layer } \\
66 \div 62 \text { for bottom layer }\end{array}$ & - & - \\
\hline $\begin{array}{l}\text { Distance between middles of steel- } \\
\text { cords in top layer of steel-cord belt and } \\
\text { middles of textile cords } \\
\text { in textile belt } x, \mathrm{~mm}\end{array}$ & $\begin{array}{c}x \\
1.20 \div 1.40\end{array}$ & & - \\
\hline
\end{tabular}

The accuracy of the parameters is $95 \%$.

Different descriptions of the structure parts of the tire-casing into the computational model of tire are possible, see Fig. 4. In relation to the computational models, the structure parts (textile carcass, textile overlap belt and steel-cord belt) are not able to be implemented up to the level of reinforcing cords because of the time difficulty as well as the large number of the finite elements. The structure parts are partially taken into account in the form of specified stiffness, or in other words, the composite component parts are partially replaced with some specified stiffness. 
Mooney-Rivlin parameters for elastomer parts of tire 165/65 R13

Table 2

\begin{tabular}{|c|c|c|c|}
\hline Mooney-Rivlin parameters & C10, MPa & C01, MPa & $\mathbf{d , ~} \mathbf{1} \cdot \mathbf{M P a}^{-1}$ \\
\hline Tread & 0.417 & 0.519 & $1.03 \mathrm{E}-01$ \\
\hline Inner liner & 0.109 & 0.259 & $2.06 \mathrm{E}-01$ \\
\hline Bead elastomer & 0.692 & 0.371 & $2.67 \mathrm{E}-01$ \\
\hline Sidewall with Tread side edge & 0.532 & 0.065 & $1.38 \mathrm{E}-01$ \\
\hline Bead bundle & -0.111 & 1.945 & $8.77 \mathrm{E}-02$ \\
\hline Elastomer drift for steel-cord belt & 0.638 & 0.284 & $1.51 \mathrm{E}-01$ \\
\hline Elastomer drift for textile overlap belt & 0.548 & 0.112 & $5.64 \mathrm{E}-02$ \\
\hline Elastomer drift for textile carcass & 0.328 & 0.119 & $1.01 \mathrm{E}-01$ \\
\hline
\end{tabular}

The authors used orthotropic material parameters for determination of the structure parts of tire as the steel-cord belt. These parameters are determined from the material parameters of the elastomer matrix and reinforcements by laminated theory used, e.g. software CADEC [7]. Two layers of the steel-cord belt with symmetrically crossed reinforcements are homogenized together and they exhibit the properties of the orthotropic material, which represents the elastomeric layer with cords (homogenization of two layers in order to make only one layer). The mentioned replacement is often used in practice. The difficulty of this method is connected with correct determination of the Poisson's ratios, which have to be calculated in order to obtain the appropriate coordinate system of the computational model representing the tire casing. Based on the sensitive analysis, high sensitivity was determined for some Poisson's ratios and it means that only a slight change can cause a significant change in the stiffness parameters of the belt as well as the whole tire casing.

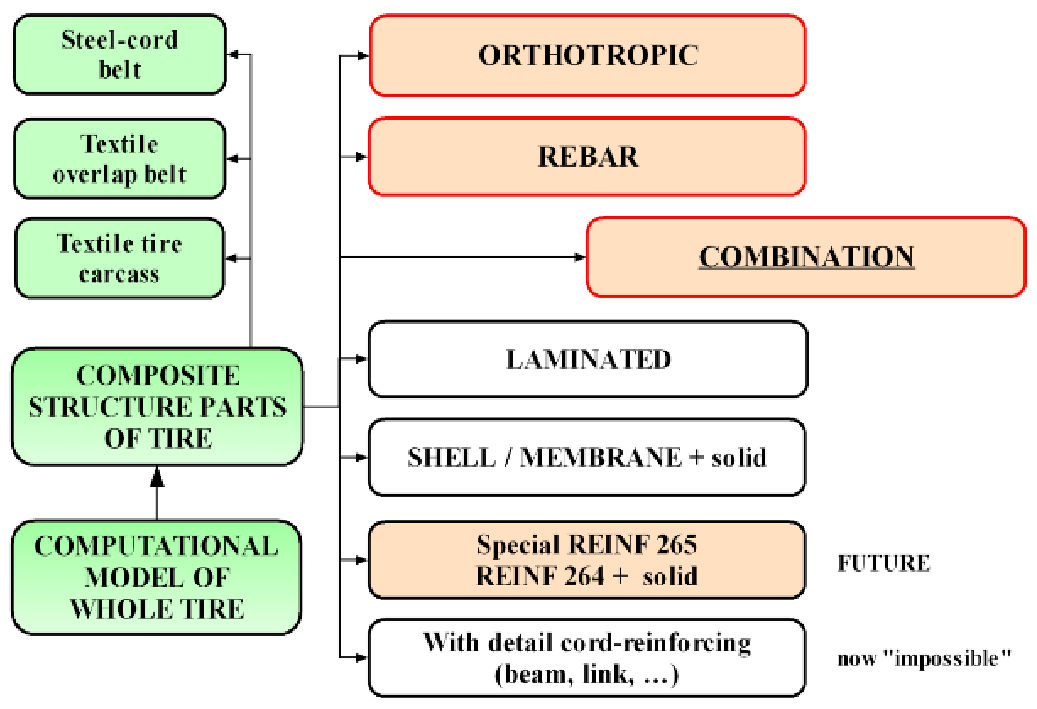

Fig. 4. Descriptions of structure parts of tire-casing [6]

\section{Results and discussion}

The values of modules of elasticity and Poisson ratios are given in Table 3 for the tire $165 / 65$ R13. These parameters can be used for computational modeling by the orthotropic material model if all structure parts are included in the geometry of the computational model. If this tire would be used in computational modeling with the orthotropic material model for definition of the tire-crown of the tire 215/40 R17 (if the area of the tire crown describes as homogenous material with the orthotropic material model, which includes the textile carcass, textile overlap belt and steel-cord belt altogether) then the modules of elasticity must be defined as input material data with these values: $230 \mathrm{MPa}$ for longitudinally direction, $215 \mathrm{MPa}$ for transverse direction and $55 \mathrm{MPa}$ for radial direction, see Fig. 5.

The values of elasticity were obtained from statical experiments of the parts of tires, according to the procedure, which was published in [8]. The computational model with these parameters is simple, 
the advantage is fast computational time and the disadvantage is the accuracy of the results. For verification analysis of the results from computational modeling the experimental data, such as vertical force-deformation dependence, stiffness of tire and next tire characteristics [9], are necessary. The experimental value of vertical stiffness of tire $165 / 65 \mathrm{R} 13$ is $185 \mathrm{~N} \cdot \mathrm{mm}^{-1}$ for $2.5 \mathrm{bar}$ and load $412 \mathrm{~kg}$. From computational modeling the value of vertical stiffness is $180 \mathrm{~N} \cdot \mathrm{mm}^{-1}$ for the same conditions. The experimental value of vertical stiffness of the low-profile tire 215/40 R17 is $260 \mathrm{~N} \cdot \mathrm{mm}^{-1}$ for 2.5 bar and load $545 \mathrm{~kg}$.

Table 3

Material parameters for composite structure of tire 165/65 R13

\begin{tabular}{|c|c|c|c|}
\hline Material parameters & $\begin{array}{c}\text { Stress modules } \\
E x / E y / E z, M P a\end{array}$ & $\begin{array}{c}\text { Main Poisson ratios } \\
P R x y / P R y z / P R x z\end{array}$ & $\begin{array}{c}\text { Shear modules } \\
G x y / G y z / G x z, M P a\end{array}$ \\
\hline Steel-cord belt & $12.0 / 23.1 / 717.0$ & $0.3122 / 0.0740 /-0.0234$ & $5.6 / 16.7 / 12.4$ \\
\hline Textile overlap belt & $21.0 / 25.4 / 745.3$ & $0.8227 / 0.0174 / 0.0132$ & $6.0 / 23.4 / 19.9$ \\
\hline Textile carcass & $12.0 / 745.1 / 21.8$ & $0.0076 / 0.4776 / 0.5481$ & $11.6 / 20.6 / 4.5$ \\
\hline
\end{tabular}

Legend: $\mathrm{x}$ - radial direction, $\mathrm{y}$ - transverse direction, $\mathrm{z}$ - longitudinally direction
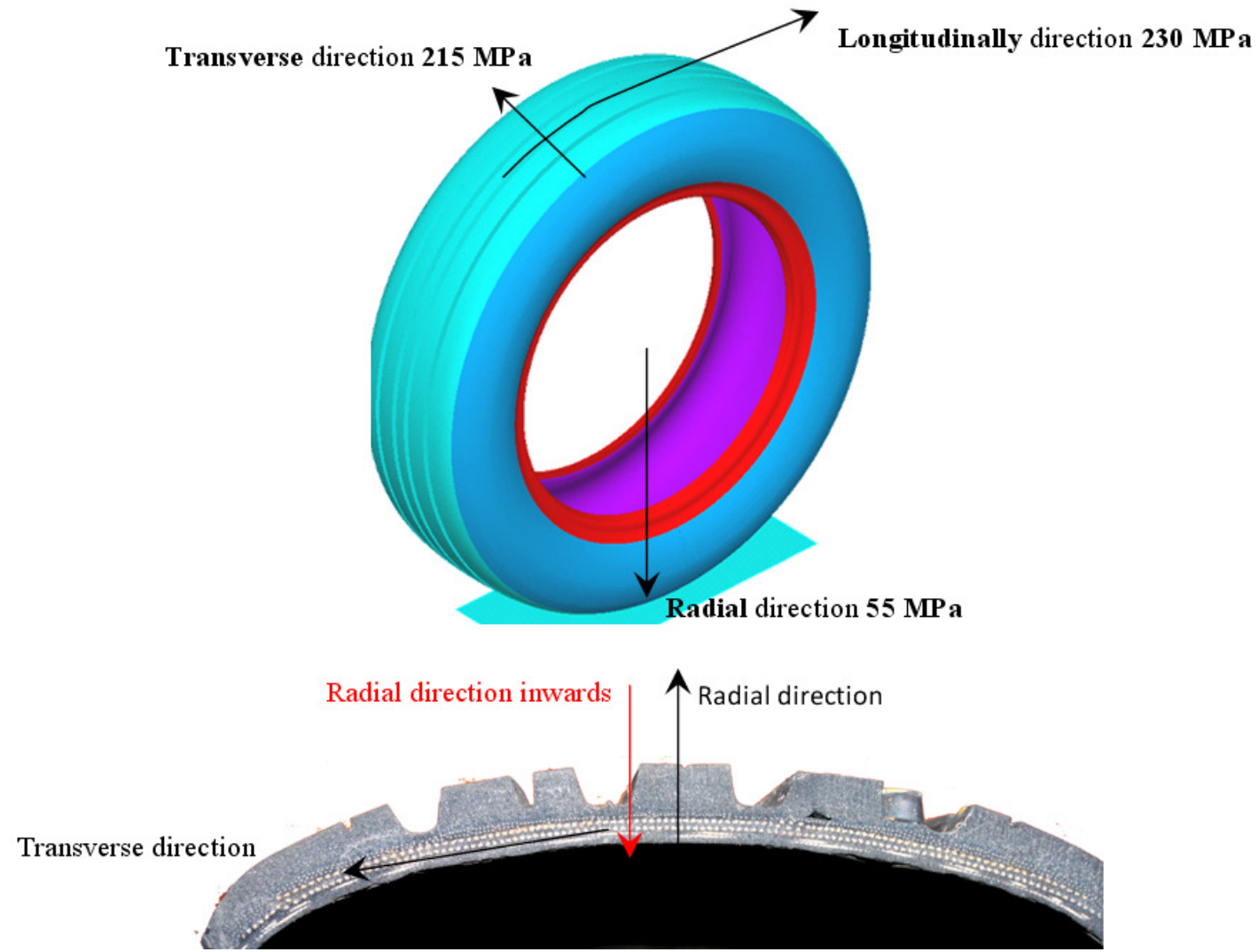

Fig. 5. Modules of elasticity of tire-crown of 215/40 R17

Next results of determination of material parameters for computational modeling and comparison (such as the size of the contact areas for different inflation pressures) between standard profile tire 165/65 R13 and low-profile tire 215/40 R17 will be also published in the new monograph with the title "Tires casing and their material characteristics for computational modeling" at the end of 2017.

\section{Conclusions}

1. It is necessary to also know the other material parameters of each individual elastomeric and reinforcing part of the tire casing for computational modeling of tires. These are the MooneyRivlin parameters of the tread, the drift rubber of carcass layers, the inner rubber, the sidewalls, the core, the bead, lateral wedge and modules of elasticity of reinforcement materials. 
2. The orthotropic material has quite good response to the surrounding environment. Therefore, the orthotropic material is often used as a replacement of, e.g., the steel-cord belt of the tire casing.

3. The geometrical and material parameters are used as inputs into the computational model of tires for strain-stress analyses of the tire. Relating to the description of the steel-cord belt for the tirecasing, special types of elements are recommended during the operation in ANSYS and these elements are, e.g., Reinf265, which is assigned to the areas of the steel-cord belt with Solid186 type of element.

\section{Acknowledgement}

This research work has been supported by the Slovak grant agency KEGA, project No. 005TnUAD-4/2016.

\section{References}

1. Krmela J., Tomanová V. Composites with nonlinear Matrix for Transport means - experimental and computational Modeling. Proceedings of $10^{\text {th }}$ International scientific conference Engineering for Rural Development, Jelgava, 2011, vol. 10, pp. 206-211. ISSN 1691-5976. [online]. Available at: http://tf.llu.lv/conference/proceedings2011/Papers/038_Krmela.pdf.

2. Koštial P., Krmela J., Frydrýšek K., Ružiak I. The Chosen Aspects of Materials and Construction Influence on the Tire Safety. Composites and Their Properties. Chap. 13. Croatia: InTech, Rijeka, 2012, pp. 265-298, DOI: 10.5772/48181. ISBN: 978-953-51-0711-8. [online]. Available at: http://www.intechopen.com/books/composites-and-their-properties/the-chosen-aspects-of-materialsand-construction-influence-on-the-tire-safety.

3. Jilek P., Šefč́́k I., Dušák L. Tires for agriculture machinery. Perner's Contacts, 2016, vol. 11, pp. 80-89. ISSN: 1801-674X. (In Czech)

4. Medvedev S., Ivanets R., Ausianka U., Kasperovich A., Mozgalev V., Prokopchuk N. Coupled Thermomechanical Computational Solutions for Stationary and Dynamics Rocking of all-metal Steel Belted Tyres. Procedia Engineering, 2016, vol. 136, pp. 8-13. DOI: 10.1016/j.proeng. 2016.01.166. ISSN 1877-7058. Available at: http://www.sciencedirect.com/science/article/pii/ S1877705816001703.

5. Krmela J., Drdáková J., Kováč I., Vido P., Pastorek M. Determination of Mooney-Rivlin Parameters of Rubber Used for Rubberizing of Steel cords as an Input for FEA Models of Tire. Metallurgical Journal (Hutnické listy), 2012, vol. 65, pp. 104-106. ISSN 00188069.

6. Krmela J., Krmelová V. Replacement of Belt Structure for FEA of Tire. Procedia Engineering, 2016, vol. 136, pp. 132-136. DOI: 10.1016/j.proeng.2016.01.186. ISSN 1877-7058. Available at: http://www.sciencedirect.com/science/article/pii/S1877705816001909.

7. Barbero E.J. CADEC (Computer Aided Design Environment for Composites) software. [online]. Available at: http://en.cadec-online.com.

8. Krmela J., Beneš L., Krmelová V. Statical experiment of tire as complex long-fibre composite for obtaining material parameters and deformation characteristic. Materials Engineering (Materialové Inžinierstvo), 2012, vol. 19, pp. 124-135. ISSN 1335-0803 (Print version), ISSN 1338-6174 (online version). Available at: http://ojs.mateng.sk/index.php/Mateng/article/view/36/44.

9. Kulikowski K., Szpica D. Determination of directional stiffnesses of vehicles' tires under a static load operation. Maintenance and Reliability (Eksploatacja i Niezawodność), 2014, vol. 16, pp. 66-72. ISSN 15072711. Available at: http://www.ein.org.pl/sites/default/files/2014-01-11.pdf. 